Citation: Tekin K. \& Biyık E. (2017), Investigation Of The Effects Of The Health Transformation Program On Public Hospitals And Health Professionals (Research In Ankara Province), BMIJ, (2017), 5(4): 190-210 doi: http://dx.doi.org/10.15295/bmij.v5i4.153

\title{
INVESTIGATION OF THE EFFECTS OF THE HEALTH TRANSFORMATION PROGRAM ON PUBLIC HOSPITALS AND HEALTH PROFESSIONALS (RESEARCHIN ANKARA PROVINCE)
}

Kemal TEKIN ${ }^{1}$

Erhan BIYIK ${ }^{2}$
Received Date (Başvuru Tarihi): 10/11/2017

Accepted Date (Kabul Tarihi): 01/01/2018

Published Date (Yaym Tarihi): 07/01/2018

\section{ABSTRACT}

AIM: The aim of this study is to investigate the effects of health applications of the Health Transformation Program (HTP) on public hospitals and health professionals.

MATERIALS AND METHODS: This descriptive and seeking relations study was conducted with the health professionals who were working in 4 public hospitals located in Ankara province. The survey was administered to 335 health professionals by using stratified sampling method. Frequen cy analysis, factor analysis, correlation, and regression analysis methods were used to analyze the data.

RESULTS: Independent variables were infrastructure, health care delivery, and management. Dependent variables were digital displays and health professional variables. Two different regression models were developed. Multiple regression models which were designed for independent and dependent variables were statistically significant. Independent variables explained almost $14 \%$ of the total variance of the digital displays and $33 \%$ of the variance of the health professionals.

CONCLUSION: The management and the representation of the health services are important forecasting toolsfor digital displays. However, the infrastructure of the health care does not have a significant effect. On the other hand, all of the independent variables are significant forecasting tools for health professionals and the Health Transformation Program (HTP) affects the health professionals more than public hospitals.

Key Words: Health transformation program, Health professionals, Public Hospital

JEL Codes: 138,118

\footnotetext{
${ }^{1}$ Yrd. Doç. Dr, Türk Hava Kurumu Üniversitesi, kemtek2003@yahoo.com

${ }^{2}$ Uzman, Yıldırım Beyazıt Eğitim ve Araştırma Hastanesi, erhanbivik@ hotmail.com
}

http://orcid.org/0000-0003-0270-4899 http://orcid.org/0000-0002-3667-8847 


\section{SAĞLIKTA DÖNÜŞÜM PROGRAMININ KAMU HASTANELERİ VE SAĞLIK PERSONELI ÜZERINDEKI ETKILERININ İNCELENMESİ (ANKARA ILINDE BİR ARAŞTIRMA)}

ÖZ

Amaç: Bu çalışma ile sağlıkta dönüşüm programı kapsamındaki uygulamaların kamu hastaneleri ve sağlık personeline etkilerinin incelenmesi amaçlanmıştır.

Gereç ve Yöntem: Betimleyici ve ilişki arayıcı tipteki bu çalışma Ankara'da 4 kamu hastanesinde görevli sağlık personeli ile yapılmıştır. Tabakalı örneklem yöntemiyle, 335 sağlık personeline anket uygulanmıştır. Verilerin analizinde frekans analizi, faktör analizi, korelasyon ve regresyon analizi yöntemleri kullan ılmıştır.

Bulgular: Bă̆ımsız değişken olarak altyapı, sağlık hizmeti sunumu ve yönetimi; bă̆ımlı değişken olarak da sayısal göstergeler ve personel değişkenleri ile 2 ayr regresyon modeli geliştirilmiştir. Bağımlı değişken ve bağımsız değişkenler için kurulan çoklu regresyon modeli istatistiksel olarak anlamlıdır. Băğımsız değiş̧kenler birlikte sayısal göstergelere ilişkin toplam varyansın yaklaşık\%14 ünü personele ilişkin varyansında \%33 ünü açıklamaktadır.

Sonuç: Să̆llk hizmetlerinin yönetimi ve să̆lık hizmeti sunumunun sayısal göstergeler üzerinde anlamlı bir tahmin aracı olduğu fakat să̆lık hizmetlerinin altyapısının önemli bir etkiye sahip olmadı̆̆l; diğer yandan bă̆ımsız değişkenlerin hepsinin sağlık personeli üzerinde anlamlı bir tahmin aracı olduğu ve Să̆lıkta Dönüşüm Programının temelde să̆lık personelini kamu hastanelerinden daha çok etkilediği tespit edilmiştir.

Anahtar Sözcükler: Să̆lıkta dönüşümprogramı, să̆lık personeli, kamu hastanesi

JEL Kodları: 138,118

\section{INTRODUCTION}

Even though the demand for health services continuously increases, the scarcity of resources allocated to the provision of services, advanced health services in countries with insufficient and ineffective health system, and the requirement to meet the demand and needs of the society have accelerated the search for the health reform (Topaca and Ekici, 2007). Since 1980s, many reforms related to health systems have been actualized in various developed and developing countries (Günaydin, 2011). The reason for the increased health service reforms in countries can be the increased health service costs. The increased costs forced countries to find solutions for more economical use of medical goods and services (Breyer and Andreas 2000).

In the middle of 1970s, the global capitalism initiated upon the contraction rate of profit falls started. In the globalization era, the nation-state's political authority has been transferred 
to international organizations, particularly to the World Bank (Etiler, 201). The economic crises forced nation states to abandon various social state applications or to make reforms for decreasing the pressures on public finances of these services (Günaydın, 2011). In this way, capitalism tends to transform public services into commodities that can be bought and sold in the market. Attempts to shift health services from public to private sector is one of these tendencies to make services so-called more efficient and profitable in developed capitalist countries (Güzelsarı, 2012).

Even though many countries in the Western world try to organize an integrated and common health services, England is the country that can provide the maximum ease of access to basic health services. Patients have more effective role while selecting the health institutions. National Health System (NHS) has been accepted. This system is still in force with many changes and updates. Unlike England, health service organizations depending on the health insurance principle have been generated in countries such as Switzerland, France and Germany. In Canada, access to health care has been made unpaid with the guarantee of public health insurance (Akdağ, 2008: and Figueras, Ray, and Elke, 2005).

Health care in the United States presents a negative picture in terms of health indicators despite high health service costs (Elbek and Adaş, 2009). The USA does not follow the previously applied liberal health system rules with the effect of the "Health Reform Law". The contribution of the state to the individual's medical expenses has been increased with the help of this new health law. In the US House of Representatives have goals such as limiting the longterm increase in the health costs and decreasing the health costs of families by health reforms accepted in $21^{\text {st }}$ of March, 2010 (Koçak and Tiryaki, 2011).

Primarily international institutions are external factors which trigger the reforms in health sector in the direction of changes. Particularly the World Bank directed its studies towards "market economy" with the report, document, fund, and consultancy services prepared in the end of 1980s. These efforts of the World Bank were supported also by IMF (Altay, 2007). Recently, the state health organization (SHO) has been tended to denationalize by recommending the public-private sector cooperation (Ener and Demircan, 2008).

In Turkey, health services were independent from market rules between 1960 and 1980. Health professionals were employed as the government employees. The administrative, organizational, and managerial structure of health services was determined according to public needs and government policies rather than the market rules and supply and demand balance 
(Güzelsar1, 2012). In 1980s, structural compliance programs led to cuts in social spending such as health and education (Kartal, 2009). Particularly after 1980, the liberization, which rapidly started to spread around the world and which further spreaded upon the collapse of The Union of Soviet Socialist Republics (USSR), influenced Turkey. These developments affected the health sector as other sectors of the economy and various private health institutions have been established after 1980s (Karabulut, 2001).

Health services increased in parallel with the increase in the health service requirements. Global developments extended the scope of the market economy, narrowed the field of public economics, and thus market-oriented development process in health services were initiated in Turkey, like other countries (Altay, 2007).

In 1990s, the restructure of the Ministry of Health within the framework of decentralization principles was frequently considered. It was emphasized in the study of "National Health Policy" that health services should be provided by professionals and decentralization principles should be adopted (Erençin and Yolcu, 2008).

1980s, despite the effort to be integrated to the world and to create more efficient heavyfunctioning health sector, political instability, changes in legislation, and law opponents prevented these initiatives. Health reform which was deteriorated in those years led to changes in the legislation required for better health reforms upon political stability and the desire of Turkey to be quickly integrated into the global world. Thus, the "Health Transformation Program” (HTP) was established (Birinci, 2013; Aksaoğlu and Giray, 2007).

Ataay (2008) specified that the current system did not entirely rely on the social state understanding and the new model which was tried to be fixed with the HTP led to radical alterations in the health and social security system and more "liberal" health system compared to the current one. Yllmaz (2008) emphasized that the alterations in the health services increased the evident in the health system between 1960 and 1980. It was also stated that the marketization of the health services officially started after 1980 by transferred the public funds to private sector because permanent health services cannot be free of charge.

According to Elbek and Adaş (2009), HTP was not initiated by the policies of the current political power. On the contrary, it has been applied since 1980s. Tips for this change lied in changing health policy post-1980s. HTP, which has been applied since 2003, does not have a 
specific content and the goals of the program coincided entirely with the seventh and eighth five-year development plans.

HTP can be classified into four main titles: The first title is composed of the restructuring of the "family medicine" system which is the first step of health services under the title of "the health clinic". The second title is composed of the restructuring of the Social Security System. Under this title, three social security institutions [Retirement Fund (Emekli Sandığ), social insurance Institution (SSK), and Tradesmen and Artisans and the SelfEmployed Social Insurance Institution (Bağ-kur)] and Green Card (social assistance restructuring) were unified under the institution named Social Security Institution (SGK) and a General Health Insurance (GHI) was established. The third title is the reorganization of second and third step health institutions with the autonomous public hospital associations with public entities. The fourth title is composed of the limitation of the reorganization of the Ministry of Health with "regulatory" functions. In this way, existing public organization, which enables the implementation of health care, has undergone a fundamental change (Ataay, 2008, Erençin and Yolcu, 2008).

The literature reveals the effects of transformation programs in health on the organizations, medical education, patient satisfaction and people working in the health sector became subjects of research. The study that is most relevant and close to this study is the $\mathrm{PhD}$ Dissertation Thesis "Transforming effects of health transformation programs in hospital organizations: A managerial Perspective" by Bostan (2009). In that study, factors are defined and differences are revealed from a managerial viewpoint. Our study develops hypotheses based on similar factors, attemps to reveal the relationships among variables are made, and future projections are made, making this study differentiated from the others.

\section{MATERIALS AND METHODS}

The universe of the study is composed of health professionals working in four public hospitals located in Ankara. The samples of the study were selected among doctors, nurses, health officials and other health professionals working in these four public hospitals. Some of the health professionals such as pharmacists, physiotherapists, health technicians/engineers were named as "other health professionals" due to their less numbers. Dentists were included in the group of doctors. Occupation variable is considered and the stratified sampling method was used in order to select the samples of the study. 
In order to determine the health professionals, universe occupation variable was divided into four layers and the sample size was calculated by using the sampling determination equation of Cochran (1962). By using this equation within the $95 \%$ confidence interval, the number of the health professionals was calculated as 335 (based on $\mathrm{d}=0.05, \mathrm{t}=1,96$ ).

The numbers of samples from each layer can be seen in Table 1.

Table 1: Targeted Sample Numbers in The Study

\begin{tabular}{cc}
\hline Layers & Number of samples \\
\hline Doctor & 114 \\
Nurse & 116 \\
Health Officers & 56 \\
Other Health Professionals & 49 \\
\hline Total & $\mathbf{3 3 5}$ \\
\hline
\end{tabular}

The samples from each layer were selected according to the calculations. As a result, it is possible to state that findings can be generalized with 5\% sampling error within a 95\% confidence interval.

A survey was used in order to collect the data of the study. The survey form is composed of two parts. In the first part, there are 7 questions related to the demographic features of the health professionals. In the second part, there are questions about the effects of the HTP on public hospitals and health professionals. These questions were evaluated under six titles with 5 Likert type scale. Totally 40 questions can be answered as follows; "1-I do not agree", "2-I less agree", "3-I am undecided", "4-I agree", and "5-I totally agree".

Some of the questions in the questionnaire used in the resereach are compiled from the research, and somen of the are designed based on the expert opinions. The questionnaire used in Bostan (2009) $\mathrm{PhD}$ thesis containing 8 factors and 89 questions is analysed and this study contributed in the preparation of the questionnaire.

At the initial step, an application is made to GATA Ethical Board, and on 07.01.2014 the board has decided that the research is compliant with the ethical rules. Afterwards, an application has been made to GATA Questionnaire Evaluation Commmission and iton 07.02.2014 the appropriateness of the questionnaire is approved. Finally, a permission request 
is made to TSK Sağlik Komutanlığı (Turkish Armed Forces) TAF Health Commander and necessary permission is received on 20.02.2014.

The survey was administered to all samples who accepted to participate in the study between $3^{\text {rd }}$ of March, 25 $5^{\text {th }}$ of March, 2014. The survey was applied by visiting the public hospitals and by using face-to-face interview technique in order to increase the feedback rate. After distributing the surveys to health professionals, they were given two days in order to have sufficient time to answer the questions. The data collection process was finalized when we reached to the targeted number of samples. Totally 370 surveys were distributed and we finally obtained 335 surveys, which was the targeted number of samples.

In order to test the reliability of the survey, the Chronbach's alpha coeffic ient was used. For instance, in the pilot study was conducted and the Chronbach's alpha coefficient was found as 0.80 according to the reliability analysis. On the other hand, the coefficient of the scale, which was calculated in the end of the study, was 0.71 . It can be stated that the scale has a high reliability.

PASW (Predictive Analytics SoftWare) Statistics 18 was used in the statistical analyses. The factor analysis was done for the 6 titles of the survey development process. 
Table 2: Factor Analysis Results (Converted Principal Component Analysis). Total Variance: 41,202

\begin{tabular}{|c|c|c|c|}
\hline Factors & Variance & İtems & Factor load \\
\hline $\begin{array}{l}\text { Health Service } \\
\text { Delivery }\end{array}$ & 6,943 & $\begin{array}{l}\text { Incentives for doctors to close the privite clinics has been a positive Application. } \\
\text { Military doctors receiving health service compensation has been a positive application. } \\
\text { Soldiers directly going to public and private hospitals has been a positive application. } \\
\text { Civilian patients directly going to the military hospital has been a positive application } \\
\text { Receiving the necessary medication from the desired pharmacy has been a positive application } \\
\text { Health service understanding is positively affected by Health Development Program } \\
\text { Collecting the public health insurance under one umbrella/has not been a positive apllication. } \\
\text { Establishment of the Patient Rights Department has been a positive application. } \\
\text { Applying the appointment system has been a positive application } \\
\text { Assignment of health personnell from Univertist Hospitals has been a positive application } \\
\text { Giving patients the right to select doctors has not been a positive application }\end{array}$ & $\begin{array}{l}0,657 \\
0,631 \\
0,579 \\
0,546 \\
0,500 \\
0,486 \\
0,474 \\
0,447 \\
0,405 \\
0,386 \\
0,322\end{array}$ \\
\hline Infrastructure & 5,367 & $\begin{array}{l}\text { Technological potential for Health development program was sufficient. } \\
\text { Public hospitals were in need of a radical transformation. } \\
\text { Trained personnel for Health Development Program(HDP)was insufficient. } \\
\text { Hospitals have sufficient capability to provide health services. } \\
\text { Economical resources for HDP were sufficient }\end{array}$ & $\begin{array}{l}0,718 \\
0,643 \\
0,609 \\
0,576 \\
0,436\end{array}$ \\
\hline Management & 7,303 & $\begin{array}{l}\text { HDP affected patient satisfaction negatively } \\
\text { HDP affected the managerial organization of the public hospitals negatively. } \\
\text { HDP affected the efficiency of the public hospitals negatively } \\
\text { HDP affected the public image of the public hospitals positively } \\
\text { Putting the automation systems into life has not been a positive application. } \\
\text { Becoming compliant with the Ministry of Health Standards has not been a positive application }\end{array}$ & $\begin{array}{l}0,557 \\
0,511 \\
0,475 \\
0,441 \\
0,372 \\
0,315\end{array}$ \\
\hline Digital Display & 7,400 & $\begin{array}{l}\text { Number of inpatients increased with HDP } \\
\text { Revenues from revolving funds increased with HDP } \\
\text { Number of doctors increased with HDP } \\
\text { Number of persnonnel increased with HDP } \\
\text { Number of walking cases decreased with HDP }\end{array}$ & $\begin{array}{l}0,633 \\
0,596 \\
0,544 \\
0,483 \\
0,435\end{array}$ \\
\hline $\begin{array}{l}\text { Personel } \\
\text { Professiona } \\
\text { ls }\end{array}$ & 8,218 & $\begin{array}{l}\text { HDP increased the salaries of personnel working in health sect or } \\
\text { HDP applications increased the professional prestige of medical personnel } \\
\text { HDP applications increased the fut ure career expectations of the medical personnel } \\
\text { HDP decreased the professional self-esteem of the medical personnel } \\
\text { HDP positively affected medical personnel satisfaction. } \\
\text { Personnel structure of the Personnel structure of the public hospitals positively affected } \\
\text { HDP increased the need to refresh the professional knowledge and abilities } \\
\text { HDP reduced the workload of medical personnel }\end{array}$ & $\begin{array}{l}0,692 \\
0,688 \\
0,650 \\
0,633 \\
0,600 \\
0,524 \\
0,413 \\
0,364\end{array}$ \\
\hline $\begin{array}{l}\text { General } \\
\text { Evaluations }\end{array}$ & 5,970 & $\begin{array}{l}\text { HDP had radical impact on Public Hospitals } \\
\text { HDP solved the problems of the public hospitals } \\
\text { HDP did not provide benefit to public hospitals } \\
\text { HDP will not provide benefit to public hospitals in the near future either } \\
\text { Patients benefitted most from HDP }\end{array}$ & $\begin{array}{l}0,470 \\
0,436 \\
0,414 \\
0,368 \\
0,364\end{array}$ \\
\hline
\end{tabular}


Kaiser Meyer Olkin (KMO) value was 0.74 according to the Principal Component Analysis of Factors. This value must be greater than 0.60 to be a factor (Büyüköztürk, 2013:136). According to the Barlett test results $\left(\left(x^{2}=3349,706, d f=780, p=0,000,<0,05\right)\right.$, it was detected that there was a relationship between variables used in the factor analyses. As a result of the factor analysis, variables were stabilized with 6 factors by considering the survey with the 6 titles and the variance rate of the factors was $41.202 \%$ as it can be seen in Table 2 after the rotation with varimax method. None of the items was removed because there was no item with the factor load less than 0.30. While the scores of the factors were being calculated, factor scores, which were found by summing the factor item values, divided to the number of the items (arithmetic mean).

In order to test whether or not the variables of the study meet the parametric test assumptions, measures of central tendency of the variables and histogram charts were examined. As a result of this test, parametric analysis techniques were preferred in the analyses of the data.

In the study, the Pearson correlation analysis was conducted for the sub dimensions of the scale in order to determine the direction and strength of the relationship between variables. The relationship was low when the correlation coefficient was between 0.00 and 0.30 , the relationship was moderate when the coefficient was between 0.30 and 0.70 , and the relations hip was at a high level when the coefficient was between 0.70 and 1.00 (Büyüköztürk, 2013).

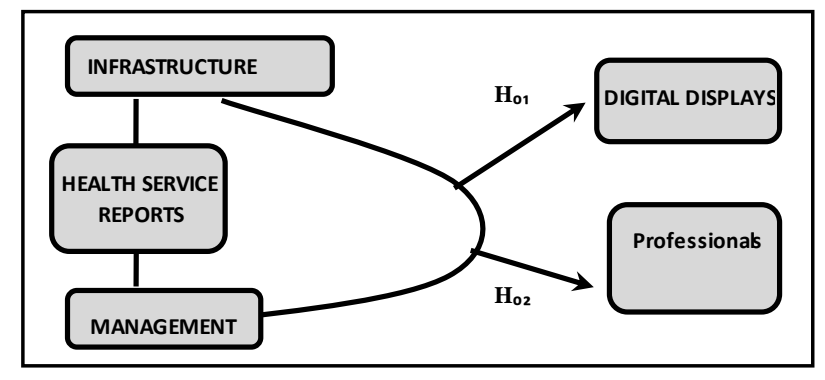

Figure 1: Research Hypotheses

In the end of the study, multiple linear regression analysis was conducted in order to explain the relationships between independent variables that were related to the dependent variable. Regression analysis was used to explain the relationships between variables by using the regression equation. It was also aimed to detect the predictive powers of the independent variables on dependent variables and their relative importance. In Figure 1, digital displays and health professionals were used as dependent variables and infrastructure, health service delivery 
and management were the dependent variables in regression models. Since there was no relationship between the general evaluations and independent variables, they were not included in the regression models. By using these models, the independent variables were HTP applications and as a result of this, we aimed to examine the effects of these applications on the hospital performance (digital displays) and the health professionals.

"Infrastructure" variable questions the physical, technological and financial conditions of the hospitals before the health transformation program. Health service relates to the health service changes made within the scope of the program. Management variable refers to managerial applications made within the scope of the change program. Numarical indicators represent the evaluation of some performance from personnel perspective. Personnel variable represents the applications related with personnel. The expressions related with these factors are given in Table 2. There are two important hypotheses in order to reach the goal of this study. $\boldsymbol{H}_{01}$ : Infrastructure, health care delivery and management factors do not lead to increase in the hospital digital displays.

$\boldsymbol{H}_{02}$ : Evaluations related to the health professional factor cannot be estimated by using infrastructure, health care delivery and management factors.

The multiple regression analysis was used to determine whether or not the relationship between the independent variables and dependent variables were linear and whether or not the scores were normally distributed. It was observed that the scatter diagram defined the linear relationship between the standardized residual and estimated values and showed that dots had a tendency to gather. Furthermore, histogram and normal distribution curves also showed a quite close distribution to the normal. When the correlation tolerance and variance inflation factor $(\mathrm{VIF}<5)$ were examined between the variables of the regression model, there was such relationship which can lead to a multicollinearity problem between independent variables. The significance level was accepted as $\mathrm{p}<0.01$.

\section{RESULTS}

The demographic characteristics of the health professionals can be seen in Table 3. According to the findings shown in Table 3, almost half of the professionals (41.8\%) were working in A hospital, majority of them were doctors (34\%) and nurses (34.6\%). The $48 . \%$ of the health professionals were male and $51.9 \%$ of them were female. Majority of the health professionals had undergraduate or higher education $(81.8 \%)$, and most of them were older than 
30 year-old $(90.1 \%)$. It is possible to state that professionals who had an occupational experience more than 20 years $(33.7 \%)$ participated in the study. The $5.4 \%$ of the professionals had an occupational experience between 1 and 4 years. Half of the professionals $(41.1 \%)$ were still working in the same hospital for between 1 and 4 years.

Table 3: Demographic Characteristics of Staff

\begin{tabular}{|c|c|c|c|}
\hline Demographic & c Characteristics & Frequency & $\begin{array}{l}\text { Percentage } \\
\%\end{array}$ \\
\hline \multirow{6}{*}{ Hospital } & A Hospital & 140 & 41,8 \\
\hline & B Hospital & 70 & 20,9 \\
\hline & C Hospital & 95 & 28,4 \\
\hline & D Hospital & 30 & 9,0 \\
\hline & Total & 335 & 100,0 \\
\hline & Doctor & 114 & 34,0 \\
\hline \multirow{4}{*}{ Task } & Nurse & 116 & 34,6 \\
\hline & Health officer & 56 & 16,7 \\
\hline & $\begin{array}{l}\text { Other health } \\
\text { professionals }\end{array}$ & 49 & 14,6 \\
\hline & Total & 335 & 100,0 \\
\hline \multirow{3}{*}{ Gender } & Male & 161 & 48,1 \\
\hline & Female & 174 & 51,9 \\
\hline & $\begin{array}{l}\text { Total } \\
\text { High School }\end{array}$ & $\begin{array}{c}335 \\
9\end{array}$ & $\begin{array}{c}100,0 \\
27\end{array}$ \\
\hline \multirow{6}{*}{ Education } & Associate Degree & 52 & 15,5 \\
\hline & Undergraduate & 129 & 38,5 \\
\hline & Master's degree & 33 & 9,9 \\
\hline & $\begin{array}{l}\mathrm{PhD} / \text { Expertise in } \\
\text { medicine }\end{array}$ & 112 & 33,4 \\
\hline & Total & 335 & 100,0 \\
\hline & $20-29$ & 33 & 9,9 \\
\hline \multirow{4}{*}{ Age } & $30-39$ & 186 & 55,5 \\
\hline & $40-49$ & 104 & 31,0 \\
\hline & 50 years or more & 12 & 3,6 \\
\hline & Total & 335 & 100,0 \\
\hline \multirow{7}{*}{$\begin{array}{l}\text { Working } \\
\text { Time in } \\
\text { Occupation }\end{array}$} & $1-4$ years & 18 & 5,4 \\
\hline & $5-9$ years & 41 & 12,2 \\
\hline & $10-14$ years & 81 & 24,2 \\
\hline & $15-19$ years & 82 & 24,5 \\
\hline & 20 years or more & 113 & 33,7 \\
\hline & Total & 335 & 100,0 \\
\hline & $1-4$ years & 138 & 41,2 \\
\hline \multirow{4}{*}{$\begin{array}{l}\text { Working } \\
\text { time in the } \\
\text { hospital }\end{array}$} & $5-9$ years & 90 & 26,9 \\
\hline & $10-14$ years & 46 & 13,7 \\
\hline & $15-19$ years & 35 & 10,4 \\
\hline & 20 years or more & 26 & 7,8 \\
\hline
\end{tabular}


In Table 4, it can be seen that there was a moderate, positive and significant relations hip between the evaluations of the health professionals towards infrastructure and the health service delivery $\left(r=0,302, p=0,000, r^{2}=0,09\right)$, there was a low, positive and significant relationship between the evaluations of the health professionals towards infrastructure and the management $\left(r=0,256, p=0,000, r^{2}=0,07\right)$, there was a low, positive and significant relationship between the evaluations of the health professionals towards infrastructure and digital displays $(r=0,223, p=$ $\left.0,000, r^{2}=0,05\right)$, there was a moderate, positive and significant relationship between the evaluations of the health professionals towards infrastructure and health professional factor $(\mathrm{r}=$ $0,354, p=0,000, r^{2}=0,13$ ), and there was a low, positive and significant relationship between the evaluations of the health professionals towards infrastructure and the general evaluations $\left(r=0,114, p=0,037, r^{2}=0,01\right)$. According to these results, as the infrastructure increases, the health service delivery, management digital displays, professional factor, and the general evaluations also increase.

It was found that there was a low, positive and significant relationship between the evaluations about the health service delivery and the digital displays $(r=0,276, p=0,000$, $\mathrm{r}^{2}=0,08$ ), and there was a moderate, positive and significant relationship between the evaluations about the health service delivery and the professional factor $(r=0,520, p=0,000$, $\mathrm{r}^{2}=0,27$ ). As a result of these findings, as the health service delivery increases, the digital displays and professional factor also increases. 
Table 4: Correlation Analysis between Variables

\begin{tabular}{|c|c|c|c|c|c|c|}
\hline & 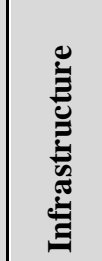 & 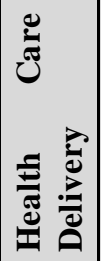 & 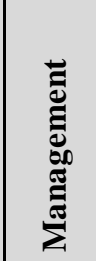 & 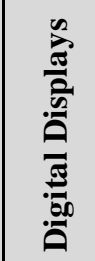 & 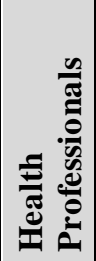 & ত \\
\hline $\begin{array}{l}\text { Infrastructure } \\
\text { Sig. (2-tailed) }\end{array}$ & 1 & & & & & \\
\hline $\begin{array}{l}\text { Health service } \\
\text { delivery } \\
\text { Sig. (2-tailed) }\end{array}$ & $302^{* *}$ & 1 & & & & \\
\hline $\begin{array}{l}\text { Management } \\
\text { Sig. (2-tailed) }\end{array}$ & $\begin{array}{l}, 256^{*} \\
* \\
, 000 \\
\end{array}$ & $\begin{array}{l}, 016 \\
, 777\end{array}$ & 1 & & & \\
\hline $\begin{array}{l}\text { Digital } \\
\text { Displays } \\
\text { Sig. (2-tailed) }\end{array}$ & $\begin{array}{l}, 223^{*} \\
* \\
, 000\end{array}$ & $\begin{array}{l}, 276^{*} \\
* \\
, 000\end{array}$ & $\begin{array}{l}, 232 \\
* * \\
000\end{array}$ & 1 & & \\
\hline $\begin{array}{l}\text { Health } \\
\text { Professionals } \\
\text { Sig. (2-tailed) }\end{array}$ & $\begin{array}{l}354^{*} \\
* \\
, 000\end{array}$ & $\begin{array}{l}, 520^{*} \\
* \\
, 000\end{array}$ & $\begin{array}{l}, 201^{*} \\
* \\
, 000\end{array}$ & $\begin{array}{l}, 367^{*} \\
* \\
, 000\end{array}$ & 1 & \\
\hline $\begin{array}{l}\text { General } \\
\text { Evaluati on } \\
\text { Sig. (2-tailed) }\end{array}$ & $\begin{array}{l}, 114^{*} \\
, 037\end{array}$ & $\begin{array}{l}, 107 \\
, 050\end{array}$ & $\begin{array}{l}, 033 \\
, 546\end{array}$ & $\begin{array}{l}, 200^{*} \\
* \\
, 000\end{array}$ & $\begin{array}{l}, 183^{*} \\
{ }^{2}, 001\end{array}$ & 1 \\
\hline$* *: \mathrm{p}<0,01$ & & & & & & \\
\hline
\end{tabular}

There was a low, positive and significant relationship between the evaluations of health professionals towards the management and the digital displays $\left(r=0,232, p=0,000, r^{2}=0,05\right)$, and there was a low, positive and significant relationship between the evaluations of health professionals towards the management and the professional factor $\left(r=0,201, p=0,000, r^{2}=\right.$ 0,04). According to our findings, as the management increases, the digital displays and the professional factor also increase.

There was a moderate, positive and significant relationship between the evaluations about digital displays and the professional factor $\left(r=0,367, p=0,000, r^{2}=0,13\right)$, and there was a low, positive and significant relationship between the evaluations about digital displays and the general evaluations $\left(r=0,200, p=0,000, r^{2}=0,04\right)$. According to these results, as the digital displays increase, the professional factor and the general evaluations also increase. 
There was a low, positive and significant relationship between the evaluations about professional factors and the general evaluations $\left(r=0,367, p=0,000, r^{2}=0,13\right)$. It can be stated that as the professional factor increases, the general evaluations also increase.

There was no significant relationship between the health service delivery and the management; health service delivery and the general evaluation; and the management and the general evaluation.

In our study, the multiple linear regression analysis results can be seen below which was used to explain the associations between more than two independent variables that were related to the dependent variables.

\section{Variables Estimate The Digital Displays Variable}

Regression analysis results about the estimations of the digital displays (dependent variable) according to the variables such as the infrastructure, health service delivery, and management can be seen in Table 5 .

According to the bilateral and partial correlations between the independent variables and the dependent variables; there was a low and positive relationship between the infrastructure and the digital displays $(r=0,223)$ whereas the correlation between these two variables was $r=0,096$ when other variables were also controlled. There was a low and positive relationship between the health service delivery and the digital displays $(r=0.276)$. When other variables were controlled, the correlation between these two variables was found as $r=0.242$. There was a low and positive relationship between the management and the digital displays ( $\mathrm{r}=$ 0,232 ) and the correlation between these two variables was $r=0,207$ when other variables were also controlled. 
Table 5: Standard Multiple Regression Analysis Results towards the digital displays estimations

\begin{tabular}{l|l|l|l|l|l}
\hline & B & $\begin{array}{l}\text { Standard } \\
\text { Error B }\end{array}$ & $\boldsymbol{\beta}$ & $\mathbf{T}$ & \\
\hline Constant &, 656 &, 286 & & 2,296 &, 002 \\
Infrastructure &, 114 &, 065 &, 097 & 1,752 &, 081 \\
Health care &, 341 &, 075 &, 244 & 4,534 &, 000 \\
Delivery &, 226 &, 059 &, 203 & 3,841 &, 000 \\
Management & $\mathrm{p}=0,000$ & & \\
\hline $\mathrm{R}=0,369$, & $\mathrm{R}^{2}=0,136$ & & \\
\hline
\end{tabular}

The multiple regression model which was created for the dependent and independent variables was statistically significant $(\mathrm{F}=17,404, \mathrm{p}=0,000)$. The multiple regression model which was created for the dependent and independent variables was statistically significant $(\mathrm{F}=$ $17,404, \mathrm{p}=0,000)$. The independent variables explained approximately the $14 \%$ of the total variance related to the digital display variable $\left(\mathrm{R}^{2}=0,136\right)$.

According to the standardized regression coefficient $(\beta)$, the relative order of the importance of the independent variables on the digital display variable is health service delivery, management, and the infrastructure, respectively. According to the Student-t test results related to the significance of the regression coefficients, it was shown that the health service delivery and the management were the significant forecasting tool on digital displays. The infrastructure did not have a significant effect $(\mathrm{p}=0.081)$.

According to these findings, $\mathbf{H}_{01}$ null hypothesis was rejected.

According to the regression analysis results, the regression equation of the digital display estimations can be seen below;

DIGITAL DISPLAYS $=0,656+0,114$ INFRASTRUCTURE $+0,341$ HEALTH SERVICE DELIVERY + 0,226 MANAGEMENT 
According to the regression equation, one unit change in the infrastructure caused 0.11 unit change, one unit change in the health service delivery caused 0.34 , and one unit change in the management caused 0.23 unit change.

\section{Variables Estimate The Health Professional Variable}

Regression analysis results about the estimations of the professional factor variable according to the variables such as the infrastructure, health service delivery, and the management can be seen in Table 5. According to the bilateral and partial correlations between the independent variables and the dependent variables; there was a moderate and positive relationship between the infrastructure and the professional $(r=0,354)$ whereas the correlation between these two variables was $r=0,194$ when other variables were also controlled. There was a moderate and positive relationship between the health service delivery and the professional $(r=0,520)$. The correlation between these two variables was $r=0,476$ when other variables were also controlled. There was a low and positive relationship between the management and the professional factor $(r=0,201)$ and the correlation between these two variables was $r=0,173$ when other variables were also controlled.

Table 6: Standard Multiple Regression Analysis Results towards the professional variable estimations

\begin{tabular}{|c|c|c|c|c|c|}
\hline & B & \begin{tabular}{|l} 
Standard \\
Error B
\end{tabular} & $\boldsymbol{\beta}$ & $\mathbf{T}$ & \\
\hline Constant & $-1,076$ &, 254 & & $\begin{array}{l}- \\
4,231\end{array}$ &, 000 \\
\hline Infrastructure & ,207 & 058 &, 175 & 3,592 &, 000 \\
\hline Health care & ,659 &, 067 & ,465 & 9,849 &, 000 \\
\hline Delivery & & & & & \\
\hline Management &, 167 & 052 &, 149 & 3,193 &, 002 \\
\hline \multicolumn{6}{|c|}{$\mathrm{R}=0,578, \quad \mathrm{R}^{2}=0,334$} \\
\hline$F_{(3,31)}=55,213$, & & $\mathrm{p}=0,000$ & & & \\
\hline
\end{tabular}

The multiple regression model which was created for the dependent and independent variables was statistically significant $(\mathrm{F}=55,213, \mathrm{p}=0,000)$. The multiple regression model which was created for the dependent and independent variables was statistically significant $(\mathrm{F}=$ 
55,213, $\mathrm{p}=0,000)$. The independent variables explain approximately the $33 \%$ of the total variance related to the professional factor variable $\left(\mathrm{R}^{2}=0,334\right)$.

According to the standardized regression coefficient $(\beta)$, the relative order of the importance of the independent variables on the professional factor variable is health service delivery, management, and the infrastructure, respectively. According to t-test results for the regression coefficient significances, it was found that health service deliver and the management variables were significant predictive tool for the digital displays $(p=0.000)$. These three variables have a significant effect on professionals.

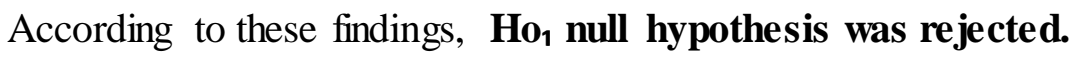

According to the regression analysis results, the regression equation of the professional variable estimation can be seen below;

PROFESSIONALS $=-1,076+0,207$ INFRASTRUCTURE $+0,659$ HEALTH SERVICE DELIVERY + 0,167 MANAGEMENT

According to the regression equation, one unit change in the infrastructure caused 0.21 unit change, one unit change in the health service delivery caused 0.66 , and one unit change in the management caused 0.17 unit change.

\section{DISCUSSION AND CONCLUSION}

The effects of the changes related with the Health Development Program on the Noational Health System have been argued for years with both positive and negative criticism, and the issue is still a topic of debate. Long-term effects of this program is another topic of discussion. Even though these transformations appear to have affected the Health Organizations more, it is observed that University and Private Health Organizations have also received their share out of this transformation.

In this study, Turkey's health policies (both current and in recent history) are examined, and this study aimed at setting direction to decision-makers while making future health policies.

In this study, effects of HTP applications on public hospitals and health professionals were examined and the participation of health professionals in the statements related to the effects of HTP applications on public hospitals and health professionals were determined. There 
were six factors such as health service delivery, the infrastructure, the management, digital displays, and general evaluations.

According to the correlation analysis, our findings showed that all factors were positively related to each other at different levels. Consequently, it was concluded that factors related to the effects of HTP should be considered as a whole. When we evaluate the power of relationships between variables, the strongest relationship was found between "professional" and "health service delivery". The weakest relationship was found between "the infrastructure" and "general evaluations".

Regression analysis was conducted in order to show the relationship between variables. Independent variables were the infrastructure, health service delivery, and professional variables.

Primarily, the predictive power of independent variables on digital displays was detected. It was detected that digital display variable can be estimated with the help of independent variables. The infrastructure did not have a significant effect among independent variables.

Finally, the predictive power of independent variables on professional variable was determined and the professional variable can be significantly estimated compared to independent variables. All of the independent variables have significant effect on the professional variable.

When we evaluate the relative importance of the independent variables, it was observed that the health service delivery variable showed the most important effect. According to the results of the study, it is possible to state that HTP had positive effects on digital displays of the public hospitals and it was dependent on the health service delivery and the qualitative increases in the management. Furthermore, effects on health professionals working in the public hospitals depended on the health service delivery, the infrastructure, and the management.

Bostan (2009) study on hospital managers to determine the transforming effect of project applications reveal that a radical and fast transformation process is experienced; most benefit of the applications is received by the Ministry of Health Hospitals, private hospitals and patients; ownership of the hospital, its geographical location and number of beds accommodated significantly affected the managerial opinions. In the study trying to express the 
differences in the viewpoints of managers, the relationship among different factors are disclosed and future projections are made.

The findings reveal that Health Transformation Program basically affects the health professionals more than public hospitals. For the development of future policies, personnel working in the health sector, main actors providing the service, has to be given more consideration. The study has shown that transformation in the health service has significant affect on health personnel, along with its effects on the performance indicators of the hospital. 


\section{REFERENCES}

Akdağ, R., 2008. Türkiye Sağlıkta Dönüşüm Programı ve Temel Sağlık Hizmetleri. Sağlık Bakanlığ1, Ankara.

Altay, A., 2007. Sağlık Hizmetlerin in Sunumunda Yeni Açılımlar ve Türkiye Açısından Değerlendirilmesi. Sayıştay Dergisi (64), 33-58.

Ataay, F., 2008. Sağlık Reformu ve Yurttaşlık Hakları. Amme İdaresi Dergisi , 41 (3), 69-184.

Birinci, Ş., 2013, November 5. Sağlik Düşüncesi ve Tıp Kültürü Platformu., Available at: http://www.sdplatform.com/Dergi/731/Saglikta-yeni-b ir-donem-Kamu-Hastaneleri-Birligi.aspx, [Access date: 04 February 2014]

Bostan, S. (2009). Sağlıkta Dönüşüm Programının Hastane İşletmeleri Üzerindeki Değişim Etkisi (Yönetici Perspektifi). (Doktora tezi). Karadeniz Teknik Üniversitesi/Sosyal Bilimler Enstitüsü, Trabzon.

Breyer, F., Haufler,A., 2000. "Health Care Reform: Separating Insurance from Income Redistribution", International Tax and Public Finance, , Kluwer Academic Publishers, Netherlands, 7, 445-461, s. 445.

Büyüköztürk, Ş., 2013. Sosyal Bilimler için Veri Analizi El Kitabı (Expanded 18. Edition). Ankara: Pegem Akademi.

Elbek, O., Adaş, E. B., 2009. Sağlıkta Dönüşüm: Eleştirel Bir Değerlendirme. Türkiye Psikiyatri Derneği Bülteni, $12(1), 33-43$

Ener, M., Demircan, E., 2008. Küresellesme Sürecinde Değisen Devlet Anlayısından Kamu Hizmetlerinin Dönüsümüne: Saglık Hizmetlerinde Piyasa Mekanizmaları. Süleyman Demirel Üniversitesi İktisadi ve İdari Bilimler Fakültesi , 3 (1), 57-82.

Erençin, A., Yolcu, V., 2008. Türkiyede Sağlık Hizmetlerin in Dönüşümü ve Yerinden Yönetimi. Memleket Siyaset Yönetim Dergisi , 3 (6), 124.

Etiler, N., 2011. Neoliberal Politikalar ve Sağlık Emekgücü Üzerindeki Etkileri. TBB Mesleki Sağlık ve Güvenlik Dergisi , 2-11.

Figueras, J, Ray R., Elke J. (ed.)., 2005 Purchasing to Improve Health Systems Performance, Europen Observatory on Health Systems and Policies Series, First Published, Glasgow, Open University Pres,

Günaydın, D., 2011. Sağlık Hizmetlerinde Küresel Reform Yaklaşımları. Sosyal Siyaset Konferansları , 1 (60), 323-365.

Güzelsarı, S., 2012. Sağlık Sisteminde Yeniden Yapılanma ve Kamu-Özel Ortaklıkları. Amme İdaresi Dergisi , 45 (3), 29-57.

Karabulut, K., 2001. Sağllk Sektöründe Özelleştirme. İktisadi ve idari Bilimler Dergisi , 15 (1-2), 31-39. 
Kartal, F., 2009. Özelleştirilen Yurttaşlık: Türkiye'de Sağlık Politikalarında Dönüşüm. Amme idaresi Dergisi , 42 (2), 23-43.

Koçak, O., Tiryaki, D., 2011. Sosyal Devlet Anlayışında Sağlık Politikalarının Önemi Ve Sağlıkta Dönüşüm Programının Değerlendirilmesi: Yalova Örneği. Istanbul Ticaret Üniversitesi Sosyal Bilimler Dergisi (19), 51-84.

Topaca, E., Ekici, B., 2007. Sağlık Sisteminde Yerinden Yönetim: Sağlık Hizmetlerinin İl Özel İdareleri ve Belediyeler Tarafindan Sunulması. Çağdaş Yerel Yönetimler , 16 (3), 49-69.

Yılmaz, B. N., 2008. Aile Hekimliği; Sağlıkta Geriye Gidişin Öyküsü. Eskişehir Tabip Odası Bülteni Sağlıkta Dönüşüm Özel Sayıs1, 4-5. 